doi: $10.26529 /$ cepsj.500

\title{
Teacher Subjectivity Regarding Assessment: Exploring English as a Foreign Language Teachers' Conceptions of Assessment Theories that Influence Student Learning
}

KInley SEden ${ }^{\star 1}$ AND Roman SvariceK ${ }^{2}$

$\approx$ Evidence shows that teachers' beliefs about the purpose of assessment are relevant with regard to how assessment is planned and implemented in classroom settings. Using a range of data sources, this qualitative interpretive study examined how 10 English as a Foreign Language teachers in Czech lower secondary schools perceived their assessment beliefs (subjective theories) and how these beliefs influenced their assessment practices within the classroom. The findings showed that although the majority of the teachers used a wide range of sources to construct their subjective theories of assessment, most of their assessment practices are still based on old-fashioned routines and in contradiction of previous research findings. An analysis of the importance of assessment practices revealed that grading, testing, questioning, and verbal feedback were used often, while self-, peer, written, and portfolio assessments were the least exercised options. Furthermore, the results indicated that the majority of the teachers used assessment for managing behaviour and for certification rather than to improve teaching and learning. The results also suggested that introducing targeted professional development courses that aim to create innovative assessment practices could contribute to transforming teaching and learning for better student learning.

Keywords: EFL teachers, subjective theory, assessment practices, assessment planning, assessment implementation

$1{ }^{\star}$ Corresponding Author. Department of Educational Sciences, Faculty of Arts, Masaryk University, the Czech Republic; kseden.sce@rub.edu.bt.

2 Department of Educational Sciences, Faculty of Arts, Masaryk University, the Czech Republic. 


\section{Subjektivnost učiteljev pri ocenjevanju: raziskovanje pojmovanj teorij ocenjevanja, ki vplivajo na učenje učencev, pri učiteljih angleščine kot tujega jezika}

Kinley Seden in Roman SvariceK

× Podatki kažejo, da so prepričanja učiteljev o namenu ocenjevanja pomembna za načrtovanje in implementacijo ocenjevanja pri pouku. Kvalitativna interpretativna študija je $\mathrm{z}$ uporabo širokega razpona podatkovnih virov raziskovala, kako deset učiteljev angleščine kot tujega jezika v čeških višjih razrednih osnovne šole dojema svoja prepričanja o ocenjevanju (subjektivne teorije) in kako ta prepričanja vplivajo na njihove ocenjevalne prakse pri pouku. Ugotovitve kažejo, da je večina ocenjevalnih praks osnovana na nesodobnih postopkih in da je $\mathrm{v}$ nasprotju s preteklimi raziskovalnimi rezultati, čeprav večina učiteljev uporablja širok razpon sredstev za konstrukcijo lastnih subjektivnih teorij ocenjevanja. Analiza pomena ocenjevalnih praks razkriva, da so bili pogosto uporabljeni ocenjevanje, testiranje, spraševanje in ustna povratna informacija, medtem ko samoocenjevanje, vrstniško in pisno ocenjevanje ter osebne mape predstavljajo manj uporabljene možnosti. Rezultati nakazujejo tudi, da je večina učiteljev uporabila ocenjevanje za upravljanje vedenja učencev in certificiranje namesto za izboljševanje poučevanja in učenja. Rezultati tudi kažejo, da uvajanje usmerjenih programov profesionalnega razvoja učiteljev, ki skušajo v pouk vpeljati inovativne ocenjevalne prakse, lahko prispeva k spremembi poučevanja za boljše učenje učencev.

Ključne besede: učitelji angleščine kot tujega jezika, subjektivna teorija, ocenjevalne prakse, načrtovanje ocenjevanja, implementacija ocenjevanja 


\section{Introduction}

Research indicates that teacher subjectivity has been proven to be an effective way to approach educational issues that can be explained from the perspectives of teachers (Diaz, Martinez, Roa, \& Sanhueza, 2010). Therefore, examining these conceptions is useful in understanding and explaining classroom assessment issues.

While a large body of research has already examined teachers' conceptions of the purpose of assessment (Barnes, Fives, \& Dacey, 2015; Brown \& Remesal, 2017; Brown, Hui, Flora, \& Kennedy, 2011; Harris, Irving, \& Peterson, 2008; Remesal, 2007; Wang, Kao, \& Lin, 2010), this remains an unexplored area in Czech schools. Since assessment and feedback are crucial to improving teaching and learning, this study will describe how English as a foreign language (EFL) teachers approach assessment, with a special focus on the ways these teachers create subjective theories about assessment in order to understand how it can support and enhance student learning.

\section{Literature Review}

The continuing need to develop the potential of classroom assessment to support learning has been emphasised by a number of researchers in the field (Assessment Reform Group, 1999). In particular, Black and Wiliam (1998b) called for research that supports teachers in attempting to establish new practices in formative assessment. In addition, Biggs (1996) claims that assessment can enhance learning only when there is constructive alignment between learning, instruction, and assessment. Recently there has been unprecedented interest shown in the link between assessment and learning, commonly referred to as formative assessment (Gardner \& Gardner, 2012). Teachers' understanding of formative assessment has proved to be central to the implementation of assessment for learning (Lee \& Coniam, 2013). At the same time, teachers who investigate and build on students' experiences, understanding, and thinking can better support students' development of understanding and engagement by functioning as a scaffold for students (Black \& Wiliam, 2009; Bransford, Brown, \& Cocking, 1999).

Sato, Wei, and Darling-Hammond (2008) highlight that the implementation of formative assessment has generated consistent learning gains for students and that there were respectable outcomes for well-articulated strategies. Black and Wiliam (1998a) stated that continuous use of formative assessment practices by teachers in their everyday classroom interactions had a strong 
relationship with increasing standards and improving student achievement. Several other studies have also reported positive impacts from assessment on learning (Crooks, 1988; Kluger \& DeNisi, 1996; Natriello, 1987); all supported the claim that the use of targeted formative assessment strategies such as questioning, feedback, self-assessment, peer assessment, and formative use of summative assessment can double the speed of student learning. More importantly, formative assessment must actively contribute to reducing the achievement gap for low achievers (Black \& Wiliam, 1998b).

Despite abundant evidence that assessment is useful in enhancing student learning, Scheerens, Ehren, Sleegers, and Leeuw (2012) and the Organization for Economic Cooperation and Development (OECD, 2005) noted that emphasis remains on summative assessment that measures what students have learned through testing and examination. The situation in the Czech Republic is no different. Research based in the Czech Republic has consistently shown the prevalence of summative assessment. For instance, Santiago, Gilmore, Nusche, and Sammons (2012) and Strakova and Simonova (2013) claim that although students in the Czech Republic are tested through both externally based examinations and ongoing formative assessments, student assessments seem to be more focused on summative results, which clearly indicates that summative assessment continues to dominate Czech classrooms.

Generally, effective assessment in the classroom occurs only rarely (Hattie, 2009; Hill, 2011). In addition, a lack of alignment and little balance between methods and results have been found in the intended use of varied assessment approaches or purposes (Santiago et al., 2012; Strakova \& Simonová, 2013; Volante \& Fazio, 2007) or between instructional goals and assessment (Campbell \& Evans, 2000; OECD, 2013). Education policies in Europe have placed growing emphasis on assessment and drawn policy attention toward the consolidation of assessment for learning in the classroom. Increasing support has been given to the concept of assessment as learning, which focuses on students reflecting on and monitoring their progress to inform their future learning (OECD, 2013). Nevertheless, several researchers have observed gaps in the capacity of teachers to implement rigorous programs of assessment for and as learning in their classrooms (Antoniou \& James, 2014; DeLuca, Luu, Sun, \& Klinger, 2012; Scheerens et al., 2012). In the Czech Republic, student performance is assessed by a plethora of instruments, from externally based examinations to ongoing daily formative assessment in the classroom; however, the OECD (2013) pointed out that assessments implemented to date at all levels of education have mirrored the weaknesses of Czech education policy and the low level of expertise in the area of assessment and evaluation in the Czech professional community. 
Researchers state that these assessments have not been well designed and had unclear goals and methodological flaws, with the most critical flaws identified in student assessment (Santiago et al., 2012). Furthermore, a content analysis study points out that classroom assessment lacks planning, portrays a wide variation in the depth of coverage with little focus related to assessment planning, and lacks theoretical connections between assessment and instructional practices (Fives, Barnes, Dacey, \& Gillis, 2016). In addition, most studies claim that teacher assessment must support learning, but several studies of lower secondary students' perceptions of teacher support have found countless opinions expressing low teacher support (Gamlem \& Munthe, 2013).

Gamlem and Munthe (2013) claim that there is a need for greater knowledge of the quality aspects of formative feedback interactions to support student learning, which was further elaborated upon by Brookhart (2011). The latter pointed to assessment-related knowledge and skills required by teachers, including being able to: (1) construct and communicate learning objectives; (2) design, draw, and use inferences from and provide feedback to students on a range of assessment options; (3) administer, interpret, and communicate the results of external assessments; and (4) help students use assessment results to inform their decisions.

Thus, at this juncture, a paradigmatic shift from teaching to learning that is generally measurable based on student learning (Kraler \& Schratz, 2012) is needed, and this calls for greater collaboration, coordination, and participation from various stakeholders, especially teachers, to take student-centred learning forward. In addition, it will require innovative ways of thinking about assessment and creative theoretical approaches that could help refine traditional concepts. Furthermore, assessment should be made more transparent and should be designed to provide greater student involvement in their assessments, as all these elements have significant potential to overcome some of the loopholes in existing approaches and connect assessment more explicitly to educational goals (Broadfoot, 2017). This can be addressed if teachers take drastic steps to develop and align their assessment practices to cater to the diverse needs of $21^{\text {st }}$-century learners. Thus, the overarching question for this study asks how EFL teachers in Czech lower secondary schools construct their subjective theories of assessment.

In exploring this question, the following sub-questions were used to guide the study:

1. What thought processes occur when teachers plan assessment practices to support learning?

2. What factors or critical incidences influence the development of teachers' subjective theories about assessment? 
As this literature review has identified a gap in the knowledge of contemporary research on Czech teachers' conceptions of assessment, the study expects to contribute to local as well as current international research on teachers' conceptions of assessment. The study may also reveal some useful measures and suggestions for the overall improvement of assessment practices with greater outcomes at producing knowledgeable and skilled teachers.

\section{Method}

In response to the research questions, the current study adopted a qualitative interpretive research design to understand the current perceptions of lower secondary teachers' conceptions about assessment and assessment practices. This research design was found to be appropriate as it allows the researcher to study participants in a natural setting, attempting to make sense of actual experiences of the participants or interpret phenomenon in terms of the meanings people bring to them (Creswell, 2003; Denzin \& Lincoln, 2011). Mishler (1990) claims that a study need not conform to an exact methodology standard; instead, each researcher can bend the methodology to the peculiarities of the setting. Agreeing with this, Miles and Huberman (1994) assert that the researcher should look behind any apparent formalism and determine what will be useful for a study.

Data consist of interviews together with lesson observations and document analysis of student work, which were used to develop the interview guide and to attain a better understanding of teachers' construction of assessment planning and implementation. The lesson observations were not recorded; however, the observer kept a diary about the observation. The observation was conducted prior to the interviews to learn more about EFL teachers' classroom assessment practices and to seek explanations and clarification to classroom observation and student work during the interviews with the teachers. One of the aims of this study was to contribute to further understanding of teachers' thought processes while planning and implementing classroom assessment practices, and so the research design was built with the purpose of investigating how classroom assessments were conceived and implemented to support learning.

Interviews were held in late fall 2017 and early spring 2018 and were conducted in an available room at the school. An interview guide was used, and the interviews were semi-structured (Kvale, 2007), developed from existing theory on classroom teaching, learning and assessment practices and assessment practices utilised in lower and elementary classes (see Appendix 1). The interviews were recorded and lasted for 60 to 90 minutes. 


\section{Context and Participants}

The setting is a government (state) school in the Czech Republic, and the schools are lower secondary in Years 7-9 (ages 13-15).

The participants were 10 EFL teachers from Czech lower secondary schools. The participants taught EFL to students between the ages of 13 to 15 . The EFL teachers were selected because English as a subject is a recent addition in Czech schools; therefore, there is a need to study how EFL teachers relate assessment practices in the EFL lessons, as assessment is significant in addressing the learning needs of students. Educational programmes designed for EFL learners (i.e., students whose first language is not English) should typically be based on objectives unique to the needs of those students. Assessment in such programmes should include assessments that attend to individual needs as well as their accomplishments. Therefore, assessment in the context of English as a Foreign Language (EFL) is explored as the majority of the assessment practices in EFL are mostly based on theories, research, and textbooks, unlike in many other subjects. In addition, the abundance of international studies on assessment in connection to EFL provides the avenue to compare findings from this study with those of the international studies.

The participants' teaching experiences ranged from two years to two decades. In the beginning, the purposeful sampling strategy was employed to elicit rich and in-depth information of an expert sample (Creswell, 2009, 2011). However, after the first few interviews, snowball sampling was used to recruit participants for the study. E-mails were sent to schools and in most instances directly to the teachers, requesting them to participate in the study. The school's principal and all the individual teachers gave informed consent to participate in the study, which had appropriate institutional ethical approval.

\section{Data collection and analysis}

A total of 15 classroom observations were made, depending on the availability of the teachers. Five teachers were observed twice while five teachers were observed once, owing to their busy schedule. The researcher kept notes on all 15 observed lessons. About 33 documents, including gap filling tests, essays, portfolios and other test materials were analysed.

The data were analysed manually following a thematic process. This approach was chosen to analyse the data because thematic analyses allow the researcher to unearth the salient themes in a text at different levels, and thematic networks aim to facilitate the structuring and depiction of these themes 
(Creswell, 2007). The analysis process started with studying the interview transcripts, classroom observation notes, and student documents carefully to note any expressions that emerged from the data that could be used as a solid basis for interpreting the findings. The process continued for several rounds before the final analysis yielded three themes, which are discussed below. Many researchers feel the need to employ a third-party consultant who can review codes or themes in order to determine the quality and effectiveness based on their evaluation of the interview transcripts (Creswell, 2007). The reliability of the data analysis was validated and confirmed by an expert. Pseudonyms were used when quoting the participants' statements.

\section{Results}

The findings of this research will be presented starting with the teachers' classroom practices and what they were thinking when they performed those practices.

\section{EFL teachers' classroom activities and assessment practices}

Although the teachers used a wide variety of classroom practices, which depended on the activities and intended purposes of the tasks carried out in the class, many of the assessment practices were mandatory. These practices included oral questioning; whole-class, individual, or pair discussions; informal observation and commenting on learners' performance; and student interaction with the teacher or peers. A variety of writing, reading, speaking, and listening exercises related to grammar and vocabulary was also included. The activities comprised exercises from the workbook, the textbook, and magazines; audio recordings; text-embedded tasks; and teacher-made tests. These activities were guided by their monthly curriculum. Most of the EFL teachers started their class with a test followed by a discussion of the tests, exercises, and workbook tasks. The small initial test was generally a gap-fill test related to vocabulary and grammar. Questioning and testing were common practices used by these EFL teachers to check students' understanding of the lesson. A few teachers were also found to use questioning as a strategy to guide classroom discussion on reading-based writing. These teachers provided a set of critical and analytical questions to assist students' reading-based writing task. The following statements by the teacher confirm this:

In class, I use mostly oral feedback and questioning. And if they are doing a writing assignment or if they are doing a test, then I use grade 
schemes or rubrics, and I make notes about what they have done correctly, what they have done incorrectly, where they need improvement, and how they can be helped. And for major assignments, I actually type up detailed notes about each criterion that they are being assessed on and hand them out, so they can see it and work on it for further improvement. (Paul)

From the above statement, it can be concluded that some teachers emphasise detailed oral and written feedback following the rubrics while some teachers used critical questions that allowed students to reflect on their work, even though the majority of teachers' questions concentrated only on recalling factual details. Hence, such a technique failed to reflect on what was being assessed.

In relation to the actual conduct of teacher assessment, most assessments seemed to take place in whole-class situations essentially to address common mistakes made by the students and mainly because such assessments do not consume much time. The empirical material indicates that the most common assessment practices in these classes consisted of testing, verbal feedback, non-verbal feedback, grading, and questioning. In many EFL classes, the teachers tested their students followed by grading and a discussion of the test. The latter was carried out with the aim of improving student learning. It was also observed that the teachers made extensive use of questioning to review and test student understanding of the topic and, at the same time, clarify and trigger more discussion of the topic during instruction, to keep students attentive and, in the end, to check whether the students had followed the lesson. Although many of the teachers' questions were found to be rhetorical and close-ended or low-level questions connected to the recollection of facts or what had been done during the lesson, the observational data revealed that some teachers used thought-provoking or open-ended questions to achieve student understanding, initiate interactions, and to promote further learning. Most of the questions were analytical and critical in nature, which fostered the development of meta-cognitive questioning skills in the students. A sample of the questions can be found below:

- Why do students prefer using interrail?

- Sometimes we tend to read the same line again and again when it didn't make any sense. Why does this happen?

- What is the mood of this passage?

- How do you know?

- Is this a narrative or descriptive text?

- What happens in the end? 
Apart from questioning and testing, the teachers also regularly used verbal feedback to communicate students' mistakes, strengths, and areas needing improvement. Such verbal feedback was generally given to the whole class, although a few teachers also took the initiative to offer feedback based on one-toone conversations. These practices were common to all teachers. The following statement by a teacher illustrates this:

During class, I mainly use oral assessment and questioning. I tell them using different techniques. I ask them what they understand, what they don't understand. I tell them where they made mistakes, where they need to work, and how it can be done. (Taylor)

The emphasis on these assessment practices seems to be strong among all ten teachers across all the lower secondary schools in the study. Each classroom observation indicated the prevalence of these practices. These were practised extensively as they were mandatory and prescribed by the institutional and education policies and also by cultural and social factors, as there is a strong culture within school and parents to determine the students', the teachers', and the schools' performances based on the grades students obtain. Therefore, these assessment practices flourish widely in all of the classes, as is voiced by one teacher:

Well, actually, school policy does not influence my beliefs, but it influences the practice of assessment because when everything has to be graded, you must show the grades. The first thing is to give a grade if they do well or not and the grades are 1-5. 1 is excellent, and 5 means fail, and so this is what most students and their parents are interested in because this is the objective expression of how well they are doing at school. (Carla)

Apart from questioning and testing, the teachers also used written assessments. These were mostly based on tests, essays, exercises from magazines, daily textbook exercises that students completed in class, and homework. Such assessments consisted mostly of corrections of grammar, spelling, and sentence structure, and comments coupled with emoticons with grades were noticeable in the notebook. In class, teachers' comments were mostly 'well done', 'good', 'excellent', 'work hard', 'you are getting there', 'interesting view', 'not bad', 'try harder', and so on. Non-verbal cues such as smiles, nodding, intonation, and gestures were also used extensively to point out student mistakes and strengths. 


\section{EFL teachers' learning, understanding, and beliefs about assessment for learning}

Teachers learning from each other and talking together about planning, and implementation has proven to be very important. The teachers in this study based their assessment conceptions from a wide range of sources. These include discussions with colleagues within their departments, the internet, observing colleagues' classroom practices, their own experience, self-learning, the students themselves, reading, podcasts, blogs, and university and school policies. The primary source for most of these teachers were consultations with colleagues in the department meetings, reading, and learning through their own experiences and exploration. The following words from one teacher illustrate this:

Well, from school, from teacher training, from working as well, I guess, the longer you work in this industry, the more different ideas you get about assessment. (Pat)

In many schools, discussions related to teaching and learning are carried out at the department meetings. All teachers in this study mentioned what assessment components should be followed, how they should follow them, and why they needed to follow them; these were discussed at length in the department. Following such discussions, a common framework was worked out for the department that was mandatory for all the teachers within the department to follow and implement in their class. One teacher also reported that in her school they discussed assessment in the language society:

Yes, for example, we have a language society at school, and there are language teachers from other languages, such as Russian and German, and we are talking together about assessment, what kind of materials we can use, and so on. (Halep)

In one school, three teachers had created their own assessment rubrics to assess and guide students' written tasks. Following the rubrics, the teachers provided timely detailed written feedback to the students indicating what, where, and how they could improve their writing. Such a culture of interaction and collaboration among teachers needs to be promoted as they lead to the creation of useful assessment practices.

The majority of the teachers' state that self-reflection assists them in bettering their practices, though one teacher communicated that observation and research aid in constructing and improving assessment practices. However, most teachers point out that their limited time and a lack of targeted and 
effective professional development courses are factors that thwarted assessment, which according to them, requires a great deal of planning and coordination. The problem appears to be that the courses were theory-oriented rather than practice-based and that there were few opportunities to attend courses due to their heavy workloads and time thresholds.

To be honest, the courses are not beneficial. Ninety per cent of the courses I've attended were useless; it's a waste of time. (Terry)

Therefore, most of the teachers perceived professional development courses as being ineffective and fruitless. Hence, such courses do not help teachers with their assessment construction.

Furthermore, all 10 of the teachers believed that self-reflection and observing their students assisted them in improving their teaching practices; thus, one of the factors that affected the way they think was their own realisation of this.

Some of the teachers had changed their assessment practices halfway through their career as they understood that this change was desirable to support learning. The empirical data below illustrates this. One of the teachers noted:

When I like something or some part of assessment [my colleagues] carry out, I try to somehow adjust and develop mine. For instance, a colleague of mine had this practice of giving small grades for various activities students do. I found that interesting and I tried this with my students too, and it worked very well as it caters to learning differentiation. (Tom)

It can be deduced from the above quote that for some teachers, some diagnostic incidents have contributed to their assessment learning.

\section{EFL teachers' subjective theories of assessment and student learning}

This section deals with EFL teachers' subjective theories regarding assessment since such theories are useful in understanding classroom assessment issues. The observation, observation notes, documents of students and interviews point to some variation in perceptions regarding classroom assessment practices.

Teachers indicated that they mostly use assessment as a strategy to motivate and engage students actively in the teaching and learning process. This can be seen as we proceed with our explanation.

The majority of teachers held the belief that the best ways to establish what students know and can do were through classroom questioning, written evidence, 
and ongoing tests and quizzes. This was reflected in the data from the classroom observation. The following statement by a teacher further confirmed this:

I usually find out what students are good at from the test, from their performance in the class. When they concentrate on the most common mistakes or when they have a written assignment, and you know there are some things that most of the students don't do well on or should, I tell them you did this well, but this wasn't good. (Carla)

Some of the teachers understood that testing was not productive and that to improve learning, different assessment approaches, including projects and portfolios, should be incorporated to allow connections with the real world and provide authenticity.

Although most of the teachers used the Grades 1 to 5 to assess student progress, there were a few teachers who had their own unique assessment methods, and these were connected to motivating and improving learning. These teachers had their own perceptions and standpoints in applying these methods. For example, three teachers claimed that they use small grades to accommodate learning differentiation and reward students' attentiveness in class. This can be seen in the following statements made by teachers:

I wrote some children some extra small grades. For example, in English if they know some interesting piece of information, for example about a festival, or if they know information about things that they have not learned before. Then, they get a small A, and when they get three small A grades, I put a circle around it. That means that three small grades are now equal to one big A grade. With this, I support them in being active. (Debra)

There were two teachers who believed in using positive comments, since they perceive negative ones to be demotivating for students and to discourage them from learning. These two teachers made frequent use of plus signs and positive reinforcement to encourage students to work harder. This can be seen in the following statements expressed by the teachers:

For example, I use only plus points not minus ones. I don't like it when somebody says that you have this many mistakes. It's better to say that you have been good at something because it's the best motivation for students, but then, I must pay attention to their mistakes as well. (Jen) Yes, for example, what usually does not work is just negative assessment. So, even if the assessment has to be negative, because the person really did not perform well, I try to find something positive. (Tom) 
Another teacher believed in applying black dots while assessing students. The black dots were used to signify offences students had committed in class. This was done to express something negative and discourage learners from doing undesirable activities. The following statement makes this clear:

I just give them little dots, but it's mostly to express when something negative happens, like when they don't have their homework, so they get one small black dot. When they get three of these, then they get a 5 in their grade book, which you know means a fail. (Taylor)

It can be concluded that these black dots were used to warn learners to be careful and to discourage them from doing anything objectionable.

The teachers regarded motivation as a crucial element in supporting student learning. The classroom observations proved that the majority of the learners in the observed EFL classes were active and highly motivated. Nonetheless, about five teachers had their own unique techniques for motivating their classes.

The observational data revealed that one of the teachers had a particular method for motivating students. The teacher used positive and negative emoticons, exercises, banging on the table, and making funny facial expressions to gain their attention; for each positive emoticon, the class got to watch a short twominute video. The teacher also awarded the learners one minute to make noise. This was permitted to prevent students from making noise throughout the lesson. The teacher stated that these activities allowed the students to move around physically and, as a result, the brain benefited from increased oxygen and thus increased brain functioning. Hence, the teacher claimed their results improved.

In addition, the teachers used the common motivational activities of organising different activities related to listening, reading, writing, and speaking, not just from the textbook, but also from other sources, such as magazines and the internet. Pair work, conversations, dialogue, group work, tests, short videos, and songs were also frequently used to motivate students. It can be concluded that there is a strong link between assessment, motivation, and student learning.

Although most of the teachers were found to be doing their best to make teaching as effective as possible and used their own unique assessment techniques to assist student learning, most of their assessment practices do not support the current research findings. This alignment should come in the form of targeted professional development courses, as it seemed that EFL teachers' assessment construction and implementation were not based on current and reliable sources, which further raises questions about the credibility and validity of their sources. 


\section{Discussion}

This study applied a qualitative-interpretive approach to explore EFL teachers' thought processes when planning and implementing assessment practices in Czech lower secondary classrooms. Although teachers acknowledged that assessment is vital in promoting student learning, the majority of their current assessment practices does not side with current research findings to support teaching and learning; rather, they were used as a basis to meet the demands of educational policies and to attend to social and cultural norms. For instance, one such example is that parents believe a child's performance is determined by the grades they obtain. This result connects with Goldstein's (2017) claim whereby he stated that constructs reflect social and cultural norms, meaning that different societies and cultures will generally assume different constructs and therefore use different assessments. Thus, these point to the fact that teachers shape their assessment practices based on existing policies and social and cultural norms, which is also consistent with findings by Harris and Brown (2009).

Furthermore, a few teachers have taken their initiatives to construct their assessment theories to support learning. Although there were some teachers who have created effective assessment theories, most of them are based on outdated methods that are against current research findings on classroom assessment practices. For example, the use of stickers, pictures, with general comments and small marks as rewards to enhance learning was clearly pointed out by Black and Wiliam, (1998) as a method that does not enhance learning. Despite this, a few EFL teachers were still found to be using them as an approach to support learning. Most teachers also indicated that incorporating fun and praising students lead to learning, which is in contrast to Black and Wiliam's (1998b) and Hattie and Timperley's (2007) research findings. Both indicate that incorporating fun into the lesson or offering praise related to the self cannot enhance learning.

However, some teachers were found to be using effective assessment practices with the aim to improve learning. For instance, these teachers were found facilitating the tasks and incorporating more interactive and discussionbased lessons. The observational data showed that about five teachers constructed analytical questions to develop students' critical thinking and understanding of reading and to guide their reading-based writing tasks. A few teachers were also found to be giving students choices between activities or projects to support learning which is consistent with Black and William's (1998) finding that indicated the common feature in students' success is by providing a diversity of 
class activities. One teacher was also found carrying out three rounds of assessment to meet the desired learning goals. The teacher practised self-, peer, and teacher assessment, which meant students went through three levels of reworking their activities before the final activities were submitted to the teacher. Black and Wiliam (1998) and Hill (2011) assert that such activities allow students to think, discuss and reflect on their own learning as well as those of their peers and to articulate their reflections and to provide feedback to each other. Furthermore, developing the learner's ability to self-assess contributes to an understanding of themselves and their learning in a fundamental way, which is rarely possible through other assessment practices (Bourke, 2016).

Additionally, the classroom observations, researcher's notes, and analysis of student work points to ample examples wherein teachers created an appropriate learning environment such as incorporating fun, giving freedom to express and explore, providing choices in projects, essay topics, giving challenging tasks, and motivational strategies like 'class, teach, smileys' and short videos to meet the desired learning outcome. This finding lends support to Biggs (1996), the 'alignment' aspect whereby teachers are expected to create appropriate and effective situations to align teaching, learning activities and assessment tasks to deliver intended learning outcomes.

A few teachers have created their own assessment rubrics to assess and guide students' written tasks. Following the rubrics, the teachers provided timely detailed written feedback to the students indicating what, where, and how they could become better at writing. They also involved the students in this assessment process, whereby students were made to do self- assessment of their work following these rubrics. In this way, the structure of the Guide, together with the conversations, served as an essential means of prompting and focusing effective self-evaluation and reflection (Boud \& Walker, 1998).

Furthermore, Tierney (2014) adds that assessment rubric criteria need to be made transparent to students by involving them in the assessment process which he sees as a multifaceted quality of classroom fairness assessment. As such, the primary goal is to support students by pointing out the need to communicate criteria to students. Such activities also developed meta-cognitive skills in both teachers and students. This is in line with Biggs's 'constructive' aspect, wherein students construct meaning through relevant learning activities (Biggs, 1996), and also with Shute (2008) and Hattie and Timperley (2007), who noted that feedback has to be specific in nature and lastly to that of Black and Wiliam (1998a), that feedback needs to give each pupil specific guidance on strengths and weaknesses, preferably without any overall marks. In one school, the teachers also construct their assessment theories by observing colleagues' 
classroom practices. Such practices if observed with a clear in a purpose and in a guided way including analysing that practice and providing feedback are seen as very useful actions in professional learning that results in improved learning for students (Adey, 2004; Parr \& Hawe, 2017).

Although there were few teachers who have initiated some innovative practices, in general, it can be concluded from the above discussion that the majority of the teachers need to rely on better sources to construct effective assessment theories reflecting current research so that their assessment practices create provisions for transparency, student engagement in the assessment process and develops the ability to self-assess, think, reflect, inquire, and articulate their learning to improve learning in the students. Additionally, the findings confirmed that the majority of the teachers implemented assessment methods mostly as a way to curb behavioural issues, which is in contrast to the current research insights of using assessment as a tool to improve teaching and learning.

Furthermore, it can be concluded that teachers' learning environments seemed to be tightly controlled by the institutional, educational, social, and cultural contexts. Such an environment needs to be replaced by an open and free environment that would motivate teachers and allow them to think outside of the box to produce innovative teaching, learning, and assessment environments within the teachers. Moreover, as proposed by Schratz (2010), the teachers can take the role of a transformative teacher, a teacher that delves more often into current research to pursue skills appropriate for the $21^{\text {st }}$ century and become more aware of social changes in order to broaden their perspectives of knowledge and skills. Unless a teacher takes these initiatives, that is, advances their own learning, improvement in student learning may not be possible.

\section{Conclusion}

This study describes the importance of teacher learning in relation to improving and supporting student learning. Based on the research findings, it can be concluded that teachers use a wide variety of sources to construct their subjective theories regarding assessment; however, most of their current practices are still found to be based on archaic routines, thus, questioning the validity, credibility and reliability of their learning sources. Therefore, the teacher participants in this study need to do a great deal in terms of advancing their learning to support student learning. The following recommendations have been suggested:

- $\quad$ Firstly, a targeted, effective professional development course leading to innovative assessment practices that align with current assessment 
research findings needs to be introduced sooner to familiarise teachers on current assessment practices, and so it can help them in planning and implementing effective formative and summative classroom assessment practices to support and improve student learning.

- Secondly, our study recommends that policymakers reconsider this critical issue in order to support teacher learning, as teachers are considered crucial individuals in students' lives.

- Thirdly, peer observation, peer feedback, collegial interaction, inquiry and reflection within the schools needs to be supported along with teacher-led workshops, whereby schools and teachers are encouraged to work in collaboration and share their best practices with each other to promote innovative teaching, learning, and assessment practices are just a few examples of teacher education.

- Fourthly, policy actions should also support the start of innovative or best practice schools to support teaching and learning.

- Finally, schools should support teachers to venture into research activities to broaden their knowledge horizons.

The limitation of the study is that it explored only EFL teachers' subjective theories of assessment. Studying subjective theories of other subject teachers would increase the validity, reliability, and credibility of the data.

\section{Acknowledgement}

The paper is part of the European Doctorate in Teacher Education (EDiTE) project that has received funding from the European Union's Horizon 2020 research and innovation programme under Marie Sklodowska-Curie grant agreement number 676452 .

\section{References}

Adey, P. (2004). The professional development of teachers: practice and theory. London, UK: Kluwer. Antoniou, P., \& James, M. (2014). Exploring formative assessment in primary school classrooms: Developing a framework of actions and strategies. Educational Assessment, Evaluation and Accountability, 26(2), 153-176.

Assessment Reform Group (1999). Assessment for learning: Beyond the black box. Cambridge, UK: University of Cambridge.

Biggs, J. (1996). Enhancing teaching through constructive alignment. Higher Education, 32(3), 347-364. Black, P., \& Wiliam, D. (2009). Developing the theory of formative assessment. Educational Assessment, 
Evaluation and Accountability, 21(1), 5. Retrieved from https://link.springer.com/article/10.1007/ \$11092-008-9068-5\#citeas

Black, P. and Wiliam, D. (1998a). Inside the black box: Raising standards through classroom assessment. Phi Delta Kappan, 8o(2), 139-148.

Black, P. and Wiliam, D. (1998b). Assessment and classroom learning. Assessment in Education, 5(1), 7-74.

Bourke, R. (2016). Liberating the learner through self-assessment. Cambridge Journal of Education, 46(1), 97-111.

Bransford, J. D., Brown, A. L., \& Cocking, R. R. (1999). How people learn: Brain, mind, and school. Washington, DC: National Research Council.

Broadfoot, P. (2017). Time to tame the leviathan? Perspectives and possibilities for a new era in assessment. Assessment in Education: Principles, Policy \& Practice, 24(3), 415-423.

Brookhart, S. M. (2011). Educational assessment knowledge and skills for teachers. Educational Measurement: Issues and Practice, 30(1), 3-12.

Brown, G. T. L., \& Remesal, A. (2017). Teachers' conceptions of assessment: Comparing two inventories with Ecuadorian teachers. Studies in Educational Evaluation, 55, 68-74.

Campbell, C., \& Evans, J. A. (2000). Investigation of preservice teachers' classroom assessment practices during student teaching. The Journal of Educational Research, 93(6), 350-355.

Creswell, J. W. (2003). Research design: Qualitative, quantitative, and mixed method approaches (3rd ed.). Los Angeles, CA: Sage Publication.

Creswell, J. W. (2007). Qualitative inquiry and research design: Choosing among five approaches (2nd ed.). Thousand Oaks, CA: Sage.

Creswell, J. W. (2009). Research Design: Qualitative, quantitative, and mixed methods approaches (3rd ed.). Thousand Oaks, CA: Sage Publications.

Creswell, J. W. (2011). Controversies in mixed methods research. In N. Denzin \& Y. S. Lincoln (Eds.), The Sage handbook of qualitative research (4th ed.) (pp. 269-283). Thousand Oaks, CA: Sage Publications.

Crooks, T. J. (1988). The impact of classroom evaluation practices on students. Review of Educational Research, 58(4), 438-481.

Denzin, N. K., \& Lincoln, Y. S. (Eds.). (2011). The Sage handbook of qualitative research. Thousand Oaks, CA: Sage.

DeLuca, C., Luu, K., Sun, Y., \& Klinger, D. A. (2012). Assessment for learning in the classroom: Barriers to implementation and possibilities for teacher professional learning. Assessment Matters, 4, 5-29.

Diaz, C., Martinez, P., Roa, I., \& Sanhueza, M. (2010). Teachers in today's society: Their beliefs and pedagogical cognitions regarding the didactic process. Polis Journal of the Bolivarian University, 9(25), $421-436$.

Fives, H., Barnes, N., Dacey, C., \& Gillis, A. (2016). Assessing Assessment texts: Where is planning? The Teacher Educator, 51(1), 70-89.

Gamlem, S. M., \& Munthe, E. (2013). Mapping the quality of feedback to support students' learning in 
lower secondary classrooms. Cambridge Journal of Education, 44(1), 75-92.

Gardner, J. N., \& Gardner, J. (Eds.). (2012). Assessmnet and learning. Thousand Oaks, CA: Sage Publications.

Goldstein, H. (2017). A response to 'assessment and learning: fields apart?' Assessment in Education: Principles, Policy \& Practice, 24(3), 388-393.

Harris, L. R., \& Brown, G. T. (2009). The complexity of teachers' conceptions of assessment: Tensions between the needs of schools and students. Assessment in Education: Principles, Policy \& Practice, 16(3), 365-381.

Harris, L., Irving, S., \& Peterson, (Eds.). (2008, December). Proceedings from annual conference of the Australian association for research in education on secondary teachers' conceptions of the purpose of assessment and feedback. Brisbane: Australia.

Hattie, J. A. (2009). Visible learning: A synthesis of 80o+ meta-analyses on achievement. Abingdon, UK: Routledge.

Hattie, J., \& Timperley, H. (2007). The power of feedback. Review of Educational Research, 77(1), 81-112. Hill, C. L. (2011). Peer editing: A comprehensive pedagogical appraoch to maximize assessment opportunities, integrate collaborative learning, and achieve desired outcomes. Nevada Law Journal, 11(3), 667-717.

Kraler, C., \& Schratz, M. (2012). From Best Practice to Next Practice: A shift through research-based teacher education. Reflecting Education, 8(2), 88-125.

Kluger, A. N., \& DeNisi, A. (1996). The effects of feedback interventions on performance: A historical review, a meta-analysis, and a preliminary feedback intervention theory. Psychological Bulletin, 119(2), $254-284$.

Kvale, S. (2007). Doing interviews. Thousand Oaks, CA: Sage Publications.

Lee, I., \& Coniam, D. (2013). Introducing assessment for learning for EFL writing in an assessment of learning examination-driven system in Hong Kong. Journal of Second Language Writing, 22(1), 34-50. Miles, M. B., \& Huberman, A. M. (1994). Qualitative data analysis: An expanded sourcebook. Los Angeles, CA: Sage.

Mishler, E. (1990). Validation in inquiry-guided research: The role of exemplars in narrative studies. Harvard Educational Review, 6o(4), 415-443.

Natriello, G. (1987). The impact of evaluation processes on students. Educational Psychologist, 22(2), 155-175.

OECD. (2005). Formative assessment: Improving learning in secondary classrooms. Paris: OECD publishing.

OECD. (2013). Synergies for better learning: An international perspective on evaluation and assessment. Paris: OECD publishing.

Parr, J. M., \& Hawe, E. (2017). Facilitating real-time observation of, and peer discussion and feedback about, practice in writing classrooms. Professional Development in Education, 43(5), 709-728.

Remesal, A. (2007). Educational reform and primary and secondary teachers' conceptions of assessment: The Spanish instance, building upon Black and Wiliam. The Curriculum Journal, 18(1), 27-38. 
Santiago, P., Gilmore, A., Nusche, D., \& Sammons, P. (2012). OECD reviews of evaluation and assessment in education. Paris: OECD Publishing.

Sato, M., Wei, R. C., \& Darling-Hammond, L. (2008). Improving Teachers' assessment practices through professional development: The Case of national board certification. American Educational Research Journal, 45(X), 669-70o.

Scheerens, J., Ehren, M., Sleegers, P., \& Leeuw, R. De. (2013). OECD Review on evaluation and assessment frameworks for improving school outcomes. Paris: OECD Publishing.

Schratz, M. (2010). What is a "European teacher"? In O. Gassner, L. Kerger, \& M. Schratz (Eds.), The first ten years after Bologna (pp. 97-102). Bukarest: Editura Universitatii din Bucuresti.

Shute, V. J. (2008). Focus on Formative Feedback. Review of Educational Research, 78(1), 153-189.

Strakova, J., \& Simonová, J. (2013). Assessment in the school systems of the Czech Republic. Assessment in Education: Principles, Policy \& Practice, 20(4), 470-490.

Tierney, R. D. (2014). Fairness as a multifaceted quality in classroom assessment. Studies in Educational Evaluation, 43(December), 55-69.

Volante, L., \& Fazio, X. (2007). Exploring teacher candidates' assessment literacy: Implications for teacher education reform and professional development. Canadian Journal of Education, 30(3), 749-770. Wang, J. R., Kao, H. L., \& Lin, S. W. (2010). Preservice teachers' initial conceptions about assessment of science learning: The coherence with their views of learning science. Teaching and Teacher Education, $26(3), 522-529$.

\section{Biographical note}

Kinley SEDEN is an early stage researcher with European Doctorate in Teacher Education (EDiTE) and a PhD student at the Department of Educational Sciences, Faculty of Arts, at Masaryk University, the Czech Republic. Her research interests include action research in the teaching and learning of economics, gender and education, teacher education and professional development.

Roman SVAriceK, PhD, is an assistant professor at the Department of Educational Sciences, Faculty of Arts at Masaryk University, the Czech Republic. His research interests include teacher professional development and classroom discourse. 